\title{
The Effect of Leverage, Receivables Turn Over, Firm Size on Financial Performance at Automotive Companies Listed at the Indonesian Stock Exchange
}

\author{
Thomas Sumarsan Goh \\ Management Department, Economics Faculty, \\ Universitas Methodist Indonesia, Medan - Indonesia
}

\author{
Melanthon Rumapea \\ Accounting Department, Economics Faculty, \\ Universitas Methodist Indonesia, Medan - Indonesia
}

\author{
Nagian Toni \\ Economics Faculty, \\ Universitas Prima Indonesia, Medan - Indonesia
}

\begin{abstract}
The global financial crisis that starting from end of 2019 until today and the trade war between China and United Stated has brought the effect to the slow down of Indonesian economic. The research aims at studying the effect of leverage, receivables turn over, firm size on financial performance at the automotive companies that have been listing at the Indonesian stock exchange, partially and simultaneously. This study has used descriptive method. The study has used time series data of the period of 2014-2019 which is expressed in yearly data. The analysis tool of the study is Multiple Regression Analysis. The results showed that simultaneously and partially, leverage, receivables turn over, firm size have significantly effected the financial performance of the automotive companies.
\end{abstract}

Keywords:- Leverage, Receivables Turn Over, Firm Size, Financial Performance.

\section{INTRODUCTION}

Every firm has the main objective, that is, to make profit and to increase the wealth of the shareholders. The responsibility of the employees in finance is to manage the assets of the company and to choose the appropriate of funding option for the company [1], [2]. The finance manager can improve the performance through the use of leverage, expedite the receipt of receivables, optimize the use of total assets. The company tries to leverage the profit and sales through making cheap or costless credit. Company can finance its operation by using the debt from suppliers or banks. The longer payment to suppliers the better the cash flow of the company is. The result from the research of Umer [3] indicates that there is a negatif and significant impact of leverage on firm's performance. However, Oyakhilome [4] and Evgeny [5] have got the result that leverage has positive impact of leverage on firm's performance.

The accounts receivables management can improve the firm's performance. The firm collects the receivables based on credit policy and alleviates the bad debt. The studies of Kilonzo [6], Patrick [7] and Ksenija [8] have shown different results on the receivables effect the firm's performance.
The firm size can give opportunity for the firm's performance. The bigger size of the firm can easily get credit from the bank. Talebria [9], Lin [10], Wright [11] and Odalo [12], have given different result in their studies.

In this study, the firm size has used total asset turn over. The asset management is very important. This study has used total assets to measure the performance. If the assets are not utilized properly will create loss in the firm. In the study of Soejono [13] have shown different results from Talebria, Lin, Wright and Odalo.

The financial performance is assumed to be influenced by the size of the companies. The bigger the company therefore the better of the company's financial performance will be. However, if the big companies do not manage their resources well, then the companies can not compete and at the end, the companies will be smaller and smaller and go bankrupt.

Based on the above background, therefore the title of this study is The Effect of Leverage, Receivables Turn over, and Firm Size on Financial Performance at Automotive Companies Listed at The Indonesian Stock Exchange.

This research has been limited to the leverage, receivables turn over, firm size, and financial performance at the automotive companies listed at the Indonesian Stock Exchange at the period of 2014 until 2019. Based on the background and the limitation of the research, therefore, the researcher determines the problem formulation as the following: have the leverage, receivables turn over, firm size effected the financial performance simultaneously and partially at the automotive companies listed at the Indonesian Stock Exchange?

The objective of this study is to know the effect of leverage, receivables turn over, and firm size on financial performance at the automotive companies listed at the Indonesian Stock Exchange at the period of 2014 until 2019. 


\section{THEORETICAL REVIEW}

Sumarsan [14], financial statements consist of the statement of financial position, comprehensive income statement, statement of changes in equity, cash flow statement and notes to financial statement.

According to Keown [15] an income statement starts with sales then substract the cost of goods sold to get gross profit. According to Brigham [16] income statement gererally starts with sales. The company tries to increase its sales in many ways.

Jensen and Meckling [17] noted the manager's interest and the interest of shareholder is not always the same and in this case, the manager who is responsible of running the firm tend to achieve his personal goals rather than maximizing returns to the shareholders.

A firm can increase its performance through leverage. Michaelas [18] and Rajan [19] noted that leverage is defined as a ratio of debt to total assets. The research of Umer, Oyakhilome and Evgeny have indicated different results. This study has used debt to equity ratio as the variable.

Griffin [20] noted that receivables are amounts owed to the entity and can take two basic forms, which are accounts receivable and notes receivable. Warren [21] says that receivables are usually a significant portion of the total current assets. The study has used accounts receivables turn over ratio as the variable.

According to Suwito and Herawaty [22], public companies listed on the Indonesian Stock Exchange can be categorized into 3 (three) large groups, namely large companies, medium companies and small companies. Determination of the size of the company is based on total assets of the company or the sales of the company or the stock market value.

The size of a company is the size of the company's capacity which is valued from the assets it has. Sutrisno [23] noted that the greater the assets of a company, it can be said that the larger the size of the company. The size of the company in this study is projected by the total assets turn over.

The study has used return on equity as the variable represents for the firm's performance.

\section{RESEARCH METHOD}

This study has used descriptive method. The population of the study are the automotive companies that have been listed at the Indonesian Stock Exchange and have submitted their audited financial statements for the period of 2014 until 2019 to the Indonesian Stock Exchange. This research has used purposive sampling technique. The purposive sampling method have the following criteria: the automotive companies are listing at the Indonesian Stock Exchange for the period of 2014 until 2019, the companies have published their audited financial statements; and the denominators of the statements are in Indonesian Rupiah (IDR).

Based on the above criteria, therefore there are 10 automotive companies for the sample. The samples are PT. Astra Internasional Tbk, PT. Astra Otoparts Tbk, PT. Indo Kordsa Tbk, PT. Good Year Indonesia Tbk, PT. Indomobil Sukses Internasional Tbk, PT. Indospring Tbk, PT. Multi Prima Sejahtera Tbk, PT. Prima Alloy Steel Universal Tbk dan PT. Selamat Sempurna Tbk.

Data collection method is documentary method by gathering literatures, journals, and audited financial statements.

Data analysis method in this study, Lindstrom [24] is multiple regression analysis. The analysis has used SPSS.

Gujarati [25] notes that the independent variable is the explanatory variable and the dependent variable is the explained variable. The independent variables in the study are leverage, receivables turn over and firm size. The firm size has used the total assets turn over. The dependent variable is financial performance, which is the profit.

\section{ANALYSIS}

The data has been processed with SPSS.

\begin{tabular}{|c|c|c|c|}
\hline & \multirow{2}{*}{ Model } & \multicolumn{2}{|c|}{ Unstandardized Coefficients } \\
\hline & & $\mathbf{B}$ & Std. Error \\
\hline \multirow[t]{4}{*}{1} & (Constant) & 056 & 055 \\
\hline & DER & ,086 & 021 \\
\hline & ARTO &,- 016 & ,006 \\
\hline & TATO &, 173 & ,059 \\
\hline
\end{tabular}

Table 1:- The Analysis Result of Coefficient of Multiple Linear Regression

Source: Data Processed, 2020 
Based on table 1, the regression model is as the following:

Performance $=0,056+0,086$ DER - 0,016 ARTO + 0,173 TATO

The above regression model has shown that:

The constant value of 0,056 shows that if the independent variables are constant, therefore the profit will increase as much as 0,056 unit.

$>$ The coefficient of DER is 0,086 . The positive sign shows that if the DER increased by $1 \%$ then the firm performance will increase $0,086(8,6 \%)$.

The coefficient of ARTO is -0.016 . The negative sign shows that if the ARTO increased by $1 \%$ then the firm performance will decrease $0,016(1,6 \%)$.

$>$ The coefficient of TATO is 0,173 . The positive sign shows that if the TATO increased by $1 \%$ then the firm performance will increase $17,3 \%$.

\begin{tabular}{|c|c|c|c|}
\hline \multicolumn{2}{|r|}{ Model } & t & Sig. \\
\hline \multirow[t]{4}{*}{1} & (Constant) & 1,019 & ,312 \\
\hline & DER & 4,035 &, 000 \\
\hline & ARTO & $-2,497$ & ,015 \\
\hline & TATO & 2,935 &, 005 \\
\hline
\end{tabular}

Table 2:- Coefficient of Partially Test

Source: Data Processed, 2020

Based on table 2, the $t_{\text {count }}$ of DER size is 4,035 with the significant error of 0,000 . The $t_{\text {table }}$ of firm size is 2,0000 . So, it can be concluded that partially, leverage (DER) has effected the financial performance positively and significantly. This has indicated that the bigger the debt of the company then the higher the profitability of the firm. The manager of the company should manage the the debt of the firm efficiently and effectively. The result is in line with the study of Oyakhilome and Evgeny.

The $t_{\text {count }}$ of ARTO is $-2,497$ with the significant error of 0.015 . The $t_{\text {table }}$ of ARTO is 2,0000. So, it can be concluded that partially, receivables turn over has effected the financial performance negatively and significantly. This has shown that the higher the receivables of the firm then the lower the profitability of the firm is. The managers of the firm should manage the firms' accounts receivable management properly in order not to suffer huge bad debts in the operation. The company tries to shorter the age of receivables, which means the bad debt becomes smaller or there is no bad debt in the company, and the result is the profit of the firm becomes higher. The result has supported the Agnes and Patrick's study. However, the result is different from the study of Ksenija and Kilonzo.

The $t_{\text {count }}$ of total assets turn over is 2,935 with the significant error of 0,005 . The $t_{\text {table }}$ of total assets turn over is 2,00000 . So, it can be concluded that partially, firm size has effected the financial performance positively and significantly. This has indicated that the improvement in the use of total assets will generate more profit. The manager should use the total assets of the company optimally, and he should decide whether the assets to use for the operation of the company, or to invest the assets to generate income from them. Finance manager can invest the idle assets in terms of buying share of other companies in order to get dividends and capital gain or buying government bonds in order to generate interest income. The result has supported the study of Lin, Wright and Odalo. The result is different from Talebria.

\begin{tabular}{|c|c|c|c|}
\hline \multicolumn{2}{|c|}{ Model } & F & Sig. \\
\hline \multirow{3}{*}{1} & Regression & 8,096 &, $000^{\mathrm{b}}$ \\
\cline { 2 - 4 } & Residual & & \\
\cline { 2 - 4 } & Total & \\
\hline \multicolumn{2}{|c|}{ a. Dependent Variable: ROE } \\
\hline \multicolumn{2}{|c|}{ b. Predictors: (Constant), DER, ARTO, TATO } \\
\hline
\end{tabular}

Table 3:- The Simultaneous Test, ANOVA

Based on table 3, the $\mathrm{F}_{\text {count }}$ of the model is 8,096 with the significant error of 0.000 . The $\mathrm{F}_{\text {table }}$ is 2.77 . So, it can be concluded that simultaneously, leverage, receivables turn over and firm sixe have effected the financial performance positively and significantly. 


\begin{tabular}{|c|c|c|c|}
\hline Model & R & R Square & Adjusted R Square \\
\hline 1 &, $550^{\mathrm{a}}$ &, 303 &, 265 \\
\hline
\end{tabular}

Table 4:- The Determination Coefficient

Source: Data processed, 2020

Based on table 4 , the coefficient of determination has shown that the R Square is 0.303 or $30.3 \%$. This has been indicated that the leverage, receivables turn over and firm size had effected the firm profit as much as $30.3 \%$, the remaing $69.7 \%$ has been effected by other factors that have not been included in this study. The other factor such as liquidity, dividend payout ratio, net working capital and other factors.

\section{RESULTS}

The results of the study are

$>$ Leverage has effected the firm's profit positively and significantly. This has indicated that the use of more debt can increase the firm performance.

The age of receivables has effected the firm's profit negatively and significantly. This has indicated that the larger the portion of receivables of the firm then the lower the profitability of the firm will be.

The firm size represents by total assets turn over has effected the financial performance positively and significantly.

$>$ The coefficient of determination has shown that the $\mathrm{R}$ Square is 0.303 or $30.3 \%$, which means that the leverage, receivables turn over and firm size had effected the profit of the firm as much as $30.3 \%$, the remaing $69.7 \%$ has been effected by other factors that have not been included in this study.

\section{CONCLUSIONS}

Based on the above analysis and results, then it can be concluded that simultaneously leverage, receivables turn over and firm size have effected the financial performance positively and significantly. Partially, leverage and firm size have effected the firm's profit positively and significantly; receivables turn over have effected the financial performance negatively and significantly. The coefficient of determination has shown that the R Square is 0.303 or $30.3 \%$. This has been indicated that the leverage, receivables turn over and firm size had effected the profit of the firm as much as $30.3 \%$, the remaing $69.7 \%$ has been effected by other factors that have not been included in this study. The other factors are as liquidity, dividend payout ratio, net working capital and other factors

\section{ACKNOWLEDGEMENTS}

The researchers would thank the Economics Faculty of the Methodist University of Indonesia, and colleagues who have supported the works and shared the ideas.

\section{REFERENCES}

[1]. Brigham, Eugene F., and Phillip R. Daves (2016) Intermediate Financial Management, $12^{\text {th }}$ Edition. United States of America: South Western, Cengage Learning.

[2]. Hidayat, Riskin. (2010). Keputusan Investasi dan Financial Contraints: Studi Empiri s pada Bursa Efek Indonesia. Buletin Ekonomi Moneter dan Perbankan. 457-479.

[3]. Iqbal, Umer and Muhammad Usman (2018). Impact of Financial Leverage on Firm Performance: Textile Composite Companies of Pakistan. Pakistan: Seisense of management. Vol.1 Issue 2.

[4]. Ibhagui, Oyakhilome W. And Felicia O. Olokoyo. (2018). Leverage and Firm Performance: New Evidence on the Role of Firm Size. North America: North American Journal of Economics and Finance 45, pp. 57-82.

[5]. Evgeny, Ilyukhin (2015). The Impact of Financial Leverage on Firm Performance: Evidence From Russia. Russia: Journal of Corporate Finance Research. Vol 2 (34), pp $24-36$.

[6]. Mbula, Kilonzo Jennifer, Memba S.F., and Njeru A. (2016). Effect of Accounts Receivabel on Financial performance of Firms Funded By Government Venture Capital In Kenya. Kenya: IOSR Journal of Economics and Finance, Vol. 7, Issue I.

[7]. Mwangi, Patrick and Agnes Mutiso. (2019). The Effect of Receivable Management On Performance of Small And Medium Scale Manufacturing Firms in Kaimbu County, Kenya. United Kingdom: International Journal of Economics, Commerce and Management, Vol. VII, Issue 8.

[8]. Mihajlov, Ksenija Dencic. (2013). Impact of Accounts Receivable Management On The Profitability During The Financial Crisis: Evidence From Serbia. The 9th International Asecu Conference On "Systemic Economic Crisis: Current Issues and Perspectives.

[9]. Talebria, Ghodratallah, Mahdi Salehi, Hashem Valipour, and Shahram Shafee. (2010). "Empirical Study of the Relationship between Ownership Structure and Firm Performance: Some Evidence of Listed Companies in Tehran Stock Exchange", Journal of Sustainable Development. Vol.3 (2), pp.264-270.

[10]. Lin, Kun Lin. (2006). Study on Related Party Transaction with Mainland China in Taiwan Enterprises, Dissertation, Management Department, Guo Li Cheng Gong University, China.

[11]. Wright, Peter and Ferris. Stephen P, (1997), “ Agency Conflict \& Corporate Strategy:The Effect of Divestment on Corporate Value", Strategic Management Journal Vol 18, 77-83. 
[12]. Odalo, Samuel K., Achoki, George., and Njuguna, Amos. (2016). Relating Company Size and Financial Performance in Agricultural Firms Listed in the Nairobi Securities Exchange in Kenya. International Journal of Economics and Finance, 8 (9): pp : 34-40

[13]. Soejono, Fransiska. (2010). Pengaruh Kepemilikan, Keputusan Investasi, Pengalaman dan Kinerja Finansial. Jurnal Bisnis dan Akuntansi. 12 (1), pp:2938.

[14]. Sumarsan, Thomas (2018) Akuntansi Dasar Dan Aplikasi Dalam Bisnis Versi IFRS Jilid 1, Edisi 2. Jakarta: Indeks.

[15]. Keown, Arthur J, John D. Martin and J. William Petty (2014) Foundation of Finance: The Logic and Practice of Financial Management. Eighth Edition. Upper Saddler. United States of America: Pearson Education, Inc.

[16]. Brigham, Eugene F., and Phillip R. Daves (2016) Intermediate Financial Management, 12th Edition. United States of America: South Western, Cengage Learning.

[17]. Jensen, M. C. and Meckling, W. H. (1976). Theory of the Firm: Managerial Behavior, Agency Costs and ownership Structure. Journal of Financial Economics, Vol. 3, No. 4, pp 305-360.

[18]. Michaelas N., Chittenden, F. and Poutziouris P. (1999). Financial policy and capital structure choice in U.K. SMEs: Empirical Evidence from Company Panel Data. Small Business Economics, Vol. 12, pp.113130.

[19]. Rajan R.G. and Zingales L. (1995). What do we know about capital structure? Some evidence from international data. Journal of Finance, vol. 50, no. 5, pp. 1421-1460.

[20]. Griffin, Michael P. (2009) MBA Fundamentals: Accounting and Finance. United States of America: Kaplan Publishing.

[21]. Warren, Carl S., James M. Reeve, Jonathan E. Duchac (2014) Financial and Managerial Accounting, 12th Edition. United States of America: South-Western Cengage Learning.

[22]. Suwito, Edy dan Arleen Herawaty (2005) Analisis Pengaruh Karakteristik Perusahaan Terhadap Tindakan Perataan Laba Yang Dilakukan Oleh Perusahaan Yang Terdaftar Di Bursa Efek Jakarta. Simposium Nasional Akuntansi VIII. Solo, 15-16.

[23]. Sutrisno (2003) Manajemen Keuangan: Teori, Konsep dan Aplikasi, Edisi pertama, Yogjakarta: Ekonisia

[24]. Lindstrom, Erik, Henrik Madsen, Jan Nygaard Nielson (2015) Statistics for Finance. United States of America: CRC Press.

[25]. Gujarati, Danador N., and Dawn C. Porter (2009) Basic Econometrics, Fifth Edition. United States of America: McGraw-Hill. 